\title{
Inadequate Description of Educational and Behavior Change Theories in Lifestyle Interventions for Type 2 Diabetes Prevention
}

\author{
Jens Aagaard-Hansen ${ }^{1 *}$, Ane Høstgaard Bonde ${ }^{1}$, Bjarne Bruun Jensen ${ }^{1}$, Louise Buhl Andersen ${ }^{2}$, Anette Lykke Hindhede ${ }^{1}$ and Helle Terkildsen Maindal ${ }^{3}$ \\ ${ }^{1}$ Steno Health Promotion Center, Steno Diabetes Center, Denmark \\ ${ }^{2}$ Department of Social Psychology, London School of Economics and Political Science, UK \\ ${ }^{3}$ Department of Public Health, Faculty of Health, Aarhus University, Denmark
}

"Corresponding author: Jens Aagaard-Hansen, Steno Health Promotion Center, Steno Diabetes Center, Niels Steensens Vej 8 , 2820 Gentofte, Denmark, Tel: +45 4443 3438; Fax: +45 3968 1048; E-mail: jxah@steno.dk

Rec date: Apr 26, 2014, Acc date: May 23, 2014, Pub date: May 27, 2014

Copyright: (c) 2014 Aagaard-Hansen J, et al. This is an open-access article distributed under the terms of the Creative Commons Attribution License, which permits unrestricted use, distribution, and reproduction in any medium, provided the original author and source are credited.

\begin{abstract}
The aim of this article is to explore the extent to which educational and behavior change theories were adequately described in studies aiming at postponing or preventing type 2 diabetes among individuals with prediabetes using lifestyle interventions. This is essential in order to design effective interventions for 'real life' settings. A number of databases were searched: Web of Science, PubMed, SCOPUS, Cochrane Library, Cross (MEDLINE, EMBASE, CUCO, BIOSIS), EPPI-Centre: Database of promoting health effectiveness reviews (DoPHER) and EPPI-Centre: The Trials Register of Promoting Health Interventions (TRoPHI). Sixteen randomized controlled trials were selected based on the criteria of prediabetes, defined as impaired glucose tolerance and/or impaired fasting glucose and efficacious lifestyle interventions (diet and/or physical activity). Only four trials made explicit reference to use of educational and behavior change theories in the development of the lifestyle interventions. Another five trials provided partial information, whereas the remaining seven did not refer to theories directly or indirectly. In order to allow replicability and comparison, future studies should explicitly describe and/or consider use of educational and behavior change theories in the development of lifestyle interventions.
\end{abstract}

Keywords: Behavior change; Diet; Education; Physical activity; Prevention; Theory; Type 2 diabetes

\section{Abbreviations:}

ADA: American Diabetes Association; BMI: Body Mass Index; CONSORT: Consolidated Standards of Reporting Trials; Credeci: Criteria for Reporting the Development and Evaluation of Complex Interventions in Healthcare; IFG: Impaired Fasting Glucose; IGT: Impaired Glucose Tolerance; PA: Physical Activity; RCT: Randomized, Controlled Trial; T2D: Type 2 Diabetes; TREND: Transparent Reporting of Evaluation with Non-Randomized Designs; WHO: World Health Organization

\section{Introduction}

Assessment of public health interventions should follow methodological rigor and at the same time take into account the complexity of implementing such interventions in real life settings. The Medical Research Council's evaluation framework [1] has become if not a golden standard, then a very common reference for development of complex primary health care interventions. In parallel to this development, researchers and editors of scientific journals have made an effort to improve the way scientific studies are reported, e.g. Consolidated Standards of Reporting Trials (CONSORT) [2], Transparent Reporting of Evaluation with Non-randomized Designs (TREND) [3] and Criteria for Reporting the Development and Evaluation of Complex Interventions in Healthcare (CreDECI) [4].

"Adequate application of behavioural science theories is essential for effective behavior change interventions. Planning and evaluation are key elements in developing health promotion programmes. Theories and empirical evidence form the basis for decisions during the planning process ...." [5]. This is in line with attempts to initiate a much needed discussion on the role of theory in health behavior change interventions [6]. This has led to explorations of the usefulness of self-efficacy [7], intervention mapping [5,8], health behavior theory [9] and self-determination theory $[10,11]$ in intervention designs.

In the field of diabetes prevention the past two decades' research has shown the efficacy of intensive lifestyle interventions (diet and physical activity (PA)) in postponing or even preventing the onset of type 2 diabetes among persons with prediabetes. The focus has now shifted to effectiveness and efficiency studies exploring how prevention interventions may be implemented in real life settings. Numerous systematic reviews on lifestyle prevention of type 2 diabetes [12-19] as well as many more scoping reviews have been conducted which mostly focused on the diabetes screening methods and outcomes rather than provision of details about the interventions used. The present article focuses on the extent to which the use of educational and behavior change theories in design of the interventions was explicitly reported.

\section{Methods}

The following electronic databases were searched in order to identify relevant literature - Web of Science, PubMed, SCOPUS, Cochrane Library, Cross (MEDLINE, EMBASE, CUCO, BIOSIS), EPPI-Centre: Database of promoting health effectiveness reviews (DoPHER), EPPI-Centre: The Trials Register of Promoting Health Interventions (TRoPHI). Variations and combinations of the following search terms were used when searching the databases: (1) 
Citation: Aagaard-Hansen J, Bonde AH, Jensen BB, Andersen LB, Hindhede AL, et al. (2014) Inadequate Description of Educational and Behavior Change Theories in Lifestyle Interventions for Type 2 Diabetes Prevention. J Diabetes Metab 5: 375 . doi: $10.4172 / 2155-6156.1000375$

Page 2 of 5

pre-diabetes, type 2 diabetes mellitus AND prevention; (2) lifestyle modification, behavior change, health promotion, patient education, intervention, prevention program; (3) physical activity, exercise, diet, weight loss, motivational interviewing, counselling, self-management. A total of 16 trials applying lifestyle interventions (diet and/or PA) with the purpose of delaying or preventing the onset of type 2 diabetes among persons with prediabetes were selected based on the criteria that they should be Randomized, Controlled Trials (RCT) including participants with prediabetes defined as impaired glucose tolerance (IGT) and/or Impaired Fasting Glucose (IFG) (according to relevant American Diabetes Association (ADA) or WHO criteria at the given time). Furthermore, only studies were included which could show significant effect on one or more of the following outcome measurements weight, Body-Mass Index (BMI), waist circumference, IGT, IFG or cumulative incidence of diabetes. No attempts were made to access additional unpublished data or data from project websites. The full texts of the articles were scrutinized with regard to use of terms directly or indirectly referring to educational and behavior change theory. It was not feasible to explore differences in outcome based on whether the trials used educational theories or not.

\section{Results}

\section{Lifestyle intervention trials}

Sixteen trials were included in the review (Table 1). Most of the 16 trials combined diet and PA intervention. Two studies (DPP [20-22] and IDDP $[23,24])$ combined lifestyle interventions with pharmaceuticals (Metformin) and some [25-30] addressed smoking and/or alcohol in addition to diet and PA. Most of the trials conducted a relatively intensive initial start-up training program followed by a maintenance program serving to sustain the behavior changes among the study participants. The interventions predominantly comprised health education sessions individually and/or in groups, face-to-face and/or via electronic social media and sometimes combined with clinical and other examinations.

\begin{tabular}{|c|c|c|c|}
\hline Trial & $\begin{array}{c}\text { Abbreviati } \\
\text { on }\end{array}$ & Reference to theory & $\begin{array}{c}\text { Reference to } \\
\text { educational and } \\
\text { behavioural } \\
\text { terms }\end{array}$ \\
\hline $\begin{array}{c}\text { Reduced-Fat Diet } \\
\text { Intervention in } \\
\text { Individuals With } \\
\text { Glucose Intolerance } \\
\text { [47] }\end{array}$ & $\begin{array}{c}\text { AUCKLAN } \\
\text { D }\end{array}$ & Self-monitoring \\
\hline $\begin{array}{c}\text { Ballarat Diabetes } \\
\text { Prevention Pilot } \\
\text { Initiative [36] }\end{array}$ & BDPPI & $\begin{array}{c}\text { Motivational } \\
\text { interviewing [37], } \\
\text { self-efficacy, self- } \\
\text { management } \\
\text { principles }\end{array}$ & \\
\hline $\begin{array}{c}\text { Diabetes Education \& } \\
\text { Prevention with a } \\
\text { Lifestyle Intervention } \\
\text { Offered at YMCA } \\
\text { [44,45] }\end{array}$ & DEPLOY & & $\begin{array}{c}\text { Empowerment, } \\
\text { self esteem }\end{array}$ \\
\hline $\begin{array}{c}\text { Diabetes Prevention } \\
\text { Program and Diabetes } \\
\text { Prevention Program } \\
\text { Outcomes Study } \\
\text { [20-22] }\end{array}$ & DPP & & $\begin{array}{c}\text { Empowerment } \\
\text { strategy, } \\
\text { motivational } \\
\text { interviewing, self- } \\
\text { monitoring }\end{array}$ \\
\hline
\end{tabular}

\begin{tabular}{|c|c|c|c|}
\hline $\begin{array}{l}\text { Diabetes Prevention } \\
\text { Study }[25,26]\end{array}$ & DPS & $\begin{array}{l}\text { Stages of Change } \\
\text { Model [32] }\end{array}$ & \\
\hline Da Qing Study $[48,49]$ & DQS & & \\
\hline $\begin{array}{l}\text { Glucose Tolerance } \\
\text { Study within the } \\
\text { Västerbotten } \\
\text { Intervention } \\
\text { Programme [27] }\end{array}$ & GT-VIP & & $\begin{array}{l}\text { Problem solving } \\
\text { techniques, } \\
\text { relapse } \\
\text { prevention, self- } \\
\text { monitoring }\end{array}$ \\
\hline $\begin{array}{c}\text { Healthy Living } \\
\text { Partnership to Prevent } \\
\text { Diabetes Study } \\
{[33,34]}\end{array}$ & HELP PD & $\begin{array}{c}\text { Social Cognitive } \\
\text { Theory [35], the } \\
\text { continuing care } \\
\text { problem-solving } \\
\text { model }\end{array}$ & \\
\hline $\begin{array}{l}\text { Indian Diabetes } \\
\quad \text { Prevention } \\
\text { Programme }[23,24]\end{array}$ & IDDP & & \\
\hline $\begin{array}{c}\text { Japanese Diabetes } \\
\text { Prevention Project } \\
{[51]}\end{array}$ & JDPP & & \\
\hline $\begin{array}{l}\text { Joetsu Diabetes } \\
\text { Prevention Trial [50] }\end{array}$ & JDPT & & \\
\hline $\begin{array}{l}\text { The 6-year Malmö } \\
\text { feasibility study [28] }\end{array}$ & MALMÖ & & \\
\hline $\begin{array}{c}\text { New Dietary } \\
\text { Education Programme } \\
{[46]}\end{array}$ & NDE & & Self management \\
\hline $\begin{array}{c}\text { Pre-diabetes Risk } \\
\text { Education and } \\
\text { Physical Activity } \\
\text { Recommendation and } \\
\text { Encouragement } \\
\text { Programme Study } \\
{[39,40]}\end{array}$ & PREPARE & $\begin{array}{l}\text { Chaiken's Dual } \\
\text { Process Theory [43], } \\
\text { Gollwitzer's } \\
\text { Implementation } \\
\text { Intentions [41], } \\
\text { Leventhal's Common } \\
\text { Sense Model [42] } \\
\text { Social Cognitive } \\
\text { Theory [35] }\end{array}$ & \\
\hline $\begin{array}{c}\text { Study on Lifestyle and } \\
\text { Impaired Glucose } \\
\text { Tolerance Maastricht } \\
{[29,30]}\end{array}$ & SLIM & & \\
\hline $\begin{array}{l}\text { The Zensharen Study } \\
\text { for Prenvention of } \\
\text { Lifestyle Diseases [52] }\end{array}$ & Zensharen & & \\
\hline
\end{tabular}

Table 1: The 16 trials included in the article and the theories and terms referred to

\section{Reference to educational and behavior change theories}

By educational theory we understand a coherent or explanatory model (e.g. 'constructivism') which provides goals, norms and standards for effective education learning processes. The notion of behavior change has connotations to behaviorism including observational processes and external (top-down) attempts to modify behavior [31]. A specific health education activity will always build on a number of pre-assumptions inspired from - or embedded in - one or more models or theories. Although these assumptions might not be explicitly described or defined, they will always guide and influence the practices carried out as part of health education and behavior change interventions. 
Citation: Aagaard-Hansen J, Bonde AH, Jensen BB, Andersen LB, Hindhede AL, et al. (2014) Inadequate Description of Educational and Behavior Change Theories in Lifestyle Interventions for Type 2 Diabetes Prevention. J Diabetes Metab 5: 375. doi: $10.4172 / 2155-6156.1000375$

Page 3 of 5

Four of the studies referred explicitly to educational or behavior change theories. DPS $[25,26]$ indicated that the Stages of Change Model $^{1}[32$ ] was used though few details were provided on the ways in which it was done. HELP PD $[33,34]$ used Social Cognitive Theory ${ }^{2}$ [35] including the concepts of self-efficacy ${ }^{3}$ and outcome expectations and incentives. BDPPI [36] mentioned Social Cognitive Theory [35], Motivational Interviewing ${ }^{4}$ [37] and self-management principles [38]. PREPARE [39,40] referred extensively to several theories such as Social Cognitive Theory [35], Gollwitzer's Implementation Intentions [41], Leventhal's Common Sense Model [42] and Chaiken's Dual Process Theory [43]. In addition PREPARE [39,40] measured selfefficacy as part of the study.

In five studies various degrees of reference were made to theoretical terminology. Some educational and psychological concepts were mentioned in passing: empowerment (DEPLOY [44,45], DPP [20-22]), self-esteem (DEPLOY [44,45]), self-management (NDE [46]), relapse prevention (GT-VIP [27]) and self-monitoring (AUCKLAND [47], DPP [20-22], GT-VIP [27]). DPP [20-22] indicated that motivational interviewing was used as a technique. GTVIP [27] mentioned problem solving techniques. Seven of the 16 trials (DQS [48,49], IDDP [23,24], JDPT [50], JDPP [51], MALMÖ [28], SLIM [29,30], Zensharen [52]) made no explicit reference to educational and behavior change principles or theories. Thus, whereas most of the trials were very specific about the content of the intervention (the what) there were hardly any mentions of how the education was conducted.

The role of social support/influence was mentioned by DEPLOY $[44,45]$ and HELP PD $[33,34]$ as a recognition of the importance of social networks. The only other study alluding to the importance of structural factors (as opposed to individual changes of lifestyle) was HELP PD $[33,34]$, which mentioned physical environment in passing.

\section{Discussion}

Among the 16 trials covered in this article only four (BDPPI [36], DPS [25,26], HELP PD [33,34] and PREPARE [39,40]) explicitly referred to educational or behavior change theories. As the whole rationale of the selected RCT-based research is to apply lifestyle interventions in order to prevent type 2 diabetes among persons with prediabetes, it is not surprising that the few theories used mainly focus on individual aspects of behavior change (as opposed to structural interventions addressing social and/or built environment). It is, however, remarkable that five of the trials made only sporadic reference to theoretical concepts and seven did not refer explicitly to theories at all. Assuming that that reflects the actual situation, it points to an under-utilization of relevant expertise from other disciplines such as education, psychology and social science.

In their recent review, Baker et al. [53] made an effort to uncover the 'behavioral strategies' utilized in seven trials of which six (DPP [20-22], DPS [25,26], DQS [48,49], IDPP [23,24], JDPP [51] and GTVIP [27]) are also covered here. They found Social Cognitive Theory [35], the Transtheoretical Model ${ }^{5}$ [32] and the Theory of Planned Behavior $^{6}[54]$ to be important. Baker et al. [53] may be right that the theories mentioned above were indeed specifically considered while planning these lifestyle interventions. But the findings in the present article seem to indicate that this is based on an interpretation of the ways the practical lifestyle interventions were designed in the seven trials, rather than explicit statements in the various articles describing them.
${ }^{1}$ The Stages of Change Model describes how behavioural change is not a sudden event, but rather a gradual process where an individual develops increasing readiness to change through the stages of precontemplation, contemplation, preparation, action and maintenance. It is not necessarily a linear progression, and there may be cases of relapse.

${ }^{2}$ The Social Cognitive Theory emphasizes how individuals' perceptions and behaviours are influenced by what they see in their social surroundings.

${ }^{3}$ Self-efficacy is a term for a person's belief in his or her own ability to reach set goals. It is a key element in the Social Cognitive Theory.

${ }^{4}$ Motivational Interviewing is a counselling technique based on a set of rules and principles that aims at engaging the person's motivation rather than imposing the professional's priorities and suggestions.

${ }^{5}$ The Transtheoretical Model conceptualizes an individual's readiness to change behaviour as described by Stages of Change.

${ }^{6}$ The Theory of Planned Behaviour is a further development of the Theory of Reasoned Action. It explores the relations between intentions and behaviour change.

Greaves et al. [55] found causal evidence that "change in weight was greater when established, well defined behavior change techniques were added to interventions", but no evidence that "interventions with an explicitly stated theoretical basis ... were more effective". These findings do not rule out the importance of educational or behavior change theory in the design of lifestyle interventions. Partly, the 'behavior change techniques' such as specific goal setting, relapse prevention and self-monitoring are implicitly based on theoretical rationales. Partly, the lack of causal evidence may be a consequence of using inappropriate theories or using them inappropriately.

In the present article we have demonstrated inadequate description and/or use of educational and behavior change theories in trials reporting lifestyle interventions for T2D prevention. This critique is not only academically motivated. Use of theories may or may not improve the interventions, but they need to be described in sufficient detail to allow progress of intervention development and replication of the intervention, if shown to be effective. In order to stimulate professional progress, academic exchange of experiences (successes as well as failures) and further scientific development of the area of prevention of type 2 diabetes, it is important to unpack, discuss and challenge the theoretical models that underpin our health education practices.

As the field of T2D prevention research is in the transition from efficacy to effectiveness and efficiency studies, it is essential that theories used are reported in sufficient detail to allow replicability, comparisons and further development. The same conclusion was reached in the recent review of Greaves et al. [55] The revised CONSORT statement propose as one of the 22 quality items for reporting trials that "precise details of the interventions intended for each group and how and when they were actually administered" be specified [2]. Though focusing on nonrandomized evaluations, the TREND Statement makes the same recommendation and makes in addition the point that "theories used in designing behavioral interventions" should be described [3]. Similarly, the CReDECI guideline highlights the importance of "description of the intervention's underlying theoretical considerations" as well as "description of all components of the intervention" [4]. The Medical Research Council guidance for evaluation of complex interventions 
Citation: Aagaard-Hansen J, Bonde AH, Jensen BB, Andersen LB, Hindhede AL, et al. (2014) Inadequate Description of Educational and Behavior Change Theories in Lifestyle Interventions for Type 2 Diabetes Prevention. J Diabetes Metab 5: 375. doi: $10.4172 / 2155-6156.1000375$

Page 4 of 5

from 2008 also emphasizes the importance of identifying and developing theory and describing the intervention clearly [1]. Abraham and Michie [56] have suggested a detailed "taxonomy of behavior change techniques used in interventions" that may assist authors in standardizing and thereby clarifying the way lifestyle interventions are reported.

This review has a potential limitation. It restricts itself to information on use of theories in interventions as described in the articles yielded by the published literature. A broader search on homepages, personal contacts, manuals and grey literature might have provided additional knowledge thereby allowing more precise comparisons. However, it could be argued that the same standards of transparency should apply to scientific articles describing health education and behavior change methodologies as pertain to standard laboratory and clinical procedures.

\section{Conclusions}

The present article provides an outline of 16 major trials addressing prediabetes by the means of lifestyle interventions - with a focus on the extent to which educational and behavior change theories had been explicitly utilized. Only four of the studies provided sufficient details, five made only sporadic reference to theoretical terms and the remaining seven did not report any information at all.

Researchers studying lifestyle interventions in general and type 2 diabetes prevention in particular should make an effort to abide to existing guidelines for reporting. More specifically, there is a need for future studies to design lifestyle interventions with direct and explicit reference to educational and behavior change theories. This will serve the double purpose of informing future research and assisting practitioners in applying the results in real life settings.

\section{Competing Interests}

The authors declare that they have no competing interests. The Steno Health Promotion Center at Steno Diabetes Center is funded by Novo Nordisk Ltd. and the Novo Nordisk Foundation.

\section{Authors' Contributions}

All authors have participated in the search phase as well as write up. LBA did the main literature search. JAH has drafted the manuscript on which other authors have commented.

\section{Acknowledgements}

We are thankful to colleagues at University of Aarhus and Steno Diabetes Center as well as anonymous reviewers for useful comments on draft manuscripts. Thanks also to the Novo Nordisk library for assistance in the literature search.

\section{References}

1. Craig P, Dieppe P, Macintyre S, Michie S, et al. (2008) Developing and evaluating complex interventions: the new Medical Research Council guidance. BMJ 337: a1655.

2. Moher D, Schulz KF, Altman DG (2001) The CONSORT statement: revised recommendations for improving the quality of reports of parallelgroup randomized trials. Lancet 357: 1191-1194.

3. Des Jarlais DC, Lyles C, Crepaz N; TREND Group (2004) Improving the reporting quality of nonrandomized evaluations of behavioral and public health interventions: the TREND statement. Am J Public Health 94: 361-366.

4. Möhler R, Bartoszek G, Köpke S, Meyer G (2012) Proposed criteria for reporting the development and evaluation of complex interventions in healthcare (CReDECI): guideline development. Int J Nurs Stud 49: 40-46.

5. Kok G, Schaalma H, Ruiter RA, van Empelen P, Brug J (2004) Intervention mapping: protocol for applying health psychology theory to prevention programmes. J Health Psychol 9: 85-98.

6. French SA, Worsley T (2004) What is the role of theory in health behavior change interventions? Int J BehavNutrPhys Act 1: 9.

7. Olander EK, Fletcher H, Williams S, Atkinson L, Turner A, et al. (2013) What are the most effective techniques in changing obese individuals' physical activity self-efficacy and behaviour: a systematic review and meta-analysis. Int J BehavNutrPhys Act 10: 29.

8. Brug J, Oenema A, Ferreira I (2005) Theory, evidence and Intervention Mapping to improve behavior nutrition and physical activity interventions. Int J BehavNutrPhys Act 2: 2 .

9. Jeffery RW (2004) How can Health Behavior Theory be made more useful for intervention research? Int J BehavNutrPhys Act 1: 10.

10. Patrick H, Williams GC (2012) Self-determination theory: its application to health behavior and complementarity with motivational interviewing. Int J BehavNutrPhys Act 9: 18 .

11. Teixeira PJ, Carraça EV, Markland D, Silva MN, Ryan RM (2012) Exercise, physical activity, and self-determination theory: a systematic review. Int J BehavNutrPhys Act 9: 78.

12. Norris SL, Zhang X, Avenell A, Gregg E, Bowman B, et al. (2005) Longterm effectiveness of weight-loss interventions in adults with prediabetes: a review. Am J Prev Med 28: 126-139.

13. Gillies CL, Abrams KR, Lambert PC, Cooper NJ, Sutton AJ, et al. (2007) Pharmacological and lifestyle interventions to prevent or delay type 2 diabetes in people with impaired glucose tolerance: systematic review and meta-analysis. BMJ 334: 299.

14. Yates T, Khunti K, Bull F, Gorely T, Davies MJ (2007) The role of physical activity in the management of impaired glucose tolerance: a systematic review. Diabetologia 50: 1116-1126.

15. Nield L, Summerbell CD, Hooper L, Whittaker V, Moore H (2008) Dietary advice for the prevention of type 2 diabetes mellitus in adults. Cochrane Database Syst Rev 16: CD005102.

16. Orozco LJ1, Buchleitner AM, Gimenez-Perez G, Roqué I Figuls M, Richter B, et al. (2008) Exercise or exercise and diet for preventing type 2 diabetes mellitus. Cochrane Database Syst Rev : CD003054.

17. Jackson L (2009) Translating the Diabetes Prevention Program into practice: a review of community interventions. Diabetes Educ 35: 309-320.

18. Norris SL, Zhang X, Avenell A, Gregg E, Schmid CH, et al. (2005) Longterm non-pharmacological weight loss interventions for adults with prediabetes. Cochrane Database Syst Rev : CD005270.

19. Steyn NP, Lambert EV, Tabana H (2009) Conference on "Multidisciplinary approaches to nutritional problems". Symposium on "Diabetes and health". Nutrition interventions for the prevention of type 2 diabetes. ProcNutrSoc 68: 55-70.

20. Knowler WC1, Barrett-Connor E, Fowler SE, Hamman RF, Diabetes Prevention Program Research Group (2002) Reduction in the incidence of type 2 diabetes with lifestyle intervention or metformin. $\mathrm{N}$ Engl J Med 346: 393-403.

21. Diabetes Prevention Program (DPP) Research Group (2002) The Diabetes Prevention Program (DPP): description of lifestyle intervention. Diabetes Care 25: 2165-2171.

22. Diabetes Prevention Program Research Group, Knowler WC, Fowler SE, Hamman RF, Christophi CA, et al. (2009) 10-year follow-up of diabetes incidence and weight loss in the Diabetes Prevention Program Outcomes Study. Lancet 374: 1677-1686.

23. Ramachandran A, Snehalatha C, Mary S, Mukesh B, Bhaskar AD, Indian Diabetes Prevention Programme (IDPP) (2006) The Indian Diabetes Prevention Programme shows that lifestyle modification and metformin 
Citation: Aagaard-Hansen J, Bonde AH, Jensen BB, Andersen LB, Hindhede AL, et al. (2014) Inadequate Description of Educational and Behavior Change Theories in Lifestyle Interventions for Type 2 Diabetes Prevention. J Diabetes Metab 5: 375. doi: $10.4172 / 2155-6156.1000375$

Page 5 of 5

prevent type 2 diabetes in Asian Indian subjects with impaired glucose tolerance (IDPP-1). Diabetologia 49: 289-297.

24. Ramachandran A, Snehalatha C (2011) Diabetes prevention programs. Med Clin North Am 95: 353-372, viii.

25. Lindström J, Louheranta A, Mannelin M, Rastas M, Salminen V, et al. (2003) The Finnish Diabetes Prevention Study (DPS): Lifestyle intervention and 3-year results on diet and physical activity. Diabetes Care 26: 3230-3236.

26. Lindström J, Ilanne-Parikka P, Peltonen M, Aunola S, Eriksson JG, et al. (2006) Sustained reduction in the incidence of type 2 diabetes by lifestyle intervention: follow-up of the Finnish Diabetes Prevention Study. Lancet 368: 1673-1679.

27. Lindahl B, Nilssön TK, Borch-Johnsen K, Røder ME, Söderberg S, et al (2009) A randomized lifestyle intervention with 5-year follow-up in subjects with impaired glucose tolerance: pronounced short-term impact but long-term adherence problems. Scand J Public Health 37: 434-442.

28. Eriksson KF, Lindgärde F (1991) Prevention of type 2 (non-insulindependent) diabetes mellitus by diet and physical exercise. The 6-year Malmö feasibility study. Diabetologia 34: 891-898.

29. Mensink M, Corpeleijn E, Feskens EJ, Kruijshoop M, Saris WH, et al. (2003) Study on lifestyle-intervention and impaired glucose tolerance Maastricht (SLIM): design and screening results. Diabetes Res ClinPract 61: 49-58.

30. Roumen C, Corpeleijn E, Feskens EJ, Mensink M, Saris WH, et al. (2008) Impact of 3-year lifestyle intervention on postprandial glucose metabolism: the SLIM study. Diabet Med 25: 597-605.

31. Holland JG, Skinner BF (1961) The analysis of behavior: A program for self-instruction. New York: McGraw Hill.

32. DiClemente CC (2005) Conceptual models and applied research: the ongoing contribution of the transtheoretical model. J Addict Nurs16: 5-12.

33. Katula JA, Vitolins MZ, Rosenberger EL, Blackwell C, Espeland MA, et al. (2010) Healthy Living Partnerships to Prevent Diabetes (HELP PD): design and methods. ContempClin Trials 31: 71-81.

34. Katula JA, Vitolins MZ, Rosenberger EL, Blackwell CS, Morgan TM, et al. (2011) One-year results of a community-based translation of the Diabetes Prevention Program: Healthy-Living Partnerships to Prevent Diabetes (HELP PD) Project. Diabetes Care 34: 1451-1457.

35. Bandura A (1986) Social foundations of thought and action: a social cognitive theory. Englewood Cliffs, NJ: Prentice-Hall.

36. Payne WR, Walsh KJ, Harvey JT, Livy MF, McKenzie KJ, et al. (2008) Effect of a low-resource-intensive lifestyle modification program incorporating gymnasium-based and home-based resistance training on type 2 diabetes risk in Australian adults. Diabetes Care 31: 2244-2250.

37. Boardman T, Catley D, Grobe JE, Little TD, Ahluwalia JS (2006) Using motivational interviewing with smokers: do therapist behaviors relate to engagement and therapeutic alliance? J Subst Abuse Treat 31: 329-339.

38. Lorig KR, Holman H (2003) Self-management education: history, definition, outcomes, and mechanisms. Ann Behav Med 26: 1-7.

39. Yates T, Davis M, Gorely T, Bull F, Khunti K (2008) Rationale, design and baseline data from the Pre-diabetes Risk Education and Physical Activity Recommendation and Encouragement (PREPARE) programme study: A randomized controlled trial. Patient EducCouns 73: 264-271.

40. Yates T, Davies M, Gorely T, Bull F, Khunti K (2009) Effectiveness of a Pragmatic Education Program Designed to Promote Walking Activity in
Individuals With Impaired Glucose Tolerance. A randomized controlled trial. Diabetes Care 32: 1404-1410.

41. Gollwitzer PM (1999) Implementation intentions: strong effect of simple plans: how can good intentions become effective behavior change strategies? American Psychol 54: 493-503.

42. Nouwen A, Urquhart Law G, Hussain S, McGovern S, Napier H (2009) Comparison of the role of self-efficacy and illness representations in relation to dietary self-care and diabetes distress in adolescents with type 1 diabetes. Psychol Health 24: 1071-1084.

43. Chaiken S (1987) The heuristic model of persuasion. In: Social influence: The Ontario symposium. Edited by Zanna MP, Olson JM, Herman CP, Hillsdale NJ: Lawrence Erlbaum Associates, Inc., Publishers: 3-39.

44. Ackermann RT, Finch EA, Brizendine E, Zhou H, Marrero DG (2008) Translating the Diabetes Prevention Program into the community. The DEPLOY Pilot Study. Am J Prev Med 35: 357-363.

45. Ackermann RT, Marrero DG (2007) Adapting the Diabetes Prevention Program lifestyle intervention for delivery in the community: the YMCA model. Diabetes Educ 33: 69, 74-75, 77-8.

46. Watanabe M, Yamaoka K, Yokotsuka M, Tango T (2003) Randomized controlled trial of a new dietary education program to prevent type 2 diabetes in a high-risk group of Japanese male workers. Diabetes Care 26 3209-3214.

47. Swinburn BA, Metcalf PA, Ley SJ (2001) Long-term (5-year) effects of a reduced-fat diet intervention in individuals with glucose intolerance. Diabetes Care 24: 619-624.

48. Pan XR, Li GW, Hu YH, Wang JX, Yang WY, et al. (1997) Effects of diet and exercise in preventing NIDDM in people with impaired glucose tolerance. The Da Qing IGT and Diabetes Study. Diabetes Care 20: 537-544

49. Li G, Zhang P, Wang J, Gregg EW, Yang W, Gong Q, et al. (2008) The long-term effect of lifestyle interventions to prevent diabetes in the China Da Qing Diabetes Prevention Study: a 20-year follow-up study. Lancet 371: 1783-1789.

50. Kawahara T, Takahashi K, Inazu T, Arao T, Kawahara C, et al. (2008) Reduced Progression to Type 2 Diabetes From Impaired Glucose Tolerance After a 2-Day In-Hospital Diabetes Educational Program. The Joetsu Diabetes Prevention Trial. Diabetes Care 31: 1949-1954.

51. Kosaka K, Noda M, Kuzuya T (2005) Prevention of type 2 diabetes by lifestyle intervention: a Japanese trial in IGT males. Diabetes Res ClinPract 67: 152-162.

52. Saito T, Watanabe M, Nishida J, Izumi T; Zensharen Study for Prenvention of Lifestyle Diseases Group (2011) Lifestyle Modification and Prevention of Type 2 Diabetes in Overweight Japanese With Impaired Fasting Glucose Levels. Arch Intern Med 171: 1352-1360.

53. Baker MK, Simpson K, Lloyd B, Bauman AE, Singh MA (2011) Behavioral strategies in diabetes prevention programs: a systematic review of randomized controlled trials. Diabetes Res ClinPract 91: 1-12.

54. Ajzen I (1991) The theory of planned behavior. Organ Behav Hum Dec 50: 179-211.

55. Greaves CJ, Sheppard KE, Abraham C, Hardeman W, The IMAGE Study Group (2011) Systematic review of reviews of intervention components associated with increased effectiveness in dietary and physical activity interventions. BMC Public Health 11: 1-12.

56. Abraham C, Michie S (2008) A Taxonomy of Behavior Change Techniques Used in Interventions. Health Psychol 27: 379-387. 